\title{
A Comprehensive Review on Food and Medicinal Prospects of Astraeus hygrometricus
}

\author{
Gunjan Biswas ${ }^{1 \#}$, Sudeshna Nandi ${ }^{2 \#, ~ D e b a s h i s ~ K u i l a ~}{ }^{1}, K^{\prime}$ rishnendu Acharya ${ }^{2 *}$
}

\section{Gunjan Biswas ${ }^{1 \#,}$, Sudeshna Nandi ${ }^{2 \#, ~ D e b a s h i s ~ K u i l a ~}{ }^{1}$, Krishnendu Acharya ${ }^{2 *}$ ${ }^{1}$ Department of Botany \& For- estry, Vidyasagar University, Mid- napore-721102, West Bengal, INDIA. ${ }^{2}$ Molecular and Applied Mycology and Plant Pathology Laboratory, Depart- ment of Botany, University of Calcutta, 35, Ballygunge Circular Road, Kolkata, 700019, West Bengal, INDIA. \\ Correspondence \\ Krishnendu Acharya}

Molecular and Applied Mycology and Plant Pathology Laboratory, Department of Botany, University of Calcutta, 35, Ballygunge Circular Road, Kolkata, 700019, West Bengal, INDIA

Phone no: 8013167310

E-mail: krish_paper@yahoo.com History

- Submission Date: 26-06-2017;

- Review completed: 10-07-2017;

- Accepted Date: 04-08-2017

DOI : 10.5530/pj.2017.6.125

Article Available online

http://www.phcogj.com/v9/i6

\section{Copyright}

(c) 2017 Phcog.Net. This is an openaccess article distributed under the terms of the Creative Commons Attribution 4.0 International license.

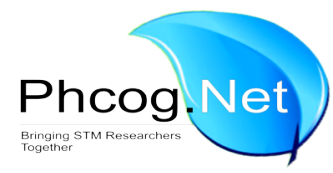

\section{ABSTRACT}

Edible mushrooms contain unique flavours and textures. They have high nutritional and medicinal values and have been consumed worldwide. Astraeus hygrometricus (Pers.) Morg. a wild ectomycorrhizal mushroom recognized as a food by the local people in South-East Asia as well as in Bihar, Jharkhand, South west India and South-Western region of West Bengal. However, it is considerably unknown to the communities in other parts of the world and it remains underutilized so far. Recent investigations from our laboratory have manifested the potential role of this mushroom in human health. Basidiocarps of $A$. hygrometricus are rich in proteins, carbohydrates, minerals, crude fibre and essential amino acids with lower concentration of fat. Experiments on animal models reveal the hepatoprotective, cardioprotective, anti-inflammatory, anticancer and hypoglycaemic efficacy of the mushroom. Additionally, researchers have found this taxon to contain many bioactive compounds shown to be responsible for antitumor, anti-leishmanial, anticandidal, antioxidant and immunomodulatory activity. The present review, summarized the scattered literature on A. hygrometricus with an emphasis on its nutritional and health promoting aspects.

Key words: Antioxidant, Astrakurkurone, Immunomodulation, Medicinal Mushroom, Nutritive Value.

\section{INTRODUCTION}

Mushrooms well recognized for their nutritional and culinary values ${ }^{1}$ are historically familiar as essential part of human health and nutrition as a substitute to plant and animal-derived products. ${ }^{2}$ Traditionally they have been used worldwide as resources of food and medicines ${ }^{3}$ and have huge potentiality in coming days to be used as regular therapeutic food. ${ }^{4}$ Edible mushrooms are low calorie-low fat food supplement with generous amount of proteins, carbohydrates, vitamins, minerals amino acids ${ }^{5}$ and dietary fibre. ${ }^{6}$ Mushroom usually possess antibacterial, antifungal, antiviral, antiparasitic, antioxidative, anti-inflammatory, antiproliferative, anticancer, anti-HIV, hypo-cholesterolemic, antidiabetic and anticoagulant activity. ${ }^{7,8}$ This review focuses on a particular mushroom, Astraeus hygrometricus, the incorporation of which in regular diet will be beneficial for human health and may be exploited as a good source of medicinal product.

Astraeus is the most common gasteromycete genera observed in temperate and tropical ecosystems. ${ }^{9}$ Till date, up to 10 species have been recorded from all around the world, distributed especially in the sandy soils of forests of Africa, Asia, Australia, Europe, Mexico, North America and South America. ${ }^{10}$ Morgan (1889) first identified Astraeus as a distinct genus with A. hygrometricus (Pers.) Morgan as the type and only species. ${ }^{11}$ In India A. hygrometricus was first identified by Ahmad. ${ }^{12}$
Astraeus hygrometricus commonly known as false earthstar is an ectomycorrhizal ${ }^{13}$ non-cultivable wild edible mushroom, belonging to Astraeaceae family ${ }^{14,15}$, growing symbiotically with the Shorea robusta G.f. roots during monsoon and post monsoon period in slightly acidic ( $\mathrm{pH} 5.5$ - 6.0) red lateritic forest soil and sandy loam soil ${ }^{16}$ Figure 1. Despite worldwide distribution of the genus, the geographical distribution of $A$. hygrometricus observed as a constricted one, dispersed mainly in China, India ${ }^{17}$ Laos, Northern Thailand ${ }^{18}$ Southern France, Trukey ${ }^{19}$ and Argentina. ${ }^{20}$

Presently vast scientific data on the nutritive and medicinal attributes of this mushroom have been offered and each of the aspects will be detailed in the following sections. Astraeus hygrometricus being a potential mushroom with edibility and therapeutic value has not been studied so much. So, this review proposes to provide a comprehensive information on the macrofungus as a valuable health promoting medicinal food so that it serves as a ready-to-use material for further research on this mushroom.

\section{NUTRITIONAL ATTRIBUTES}

Since antiquity man has been stalking for wild mushrooms as a source of food due to their chemical composition which is quite appealing from the 
Table 1: Macronutrients and energy content of Astraeus hygrometricuus. Food energy is calculated using the equation: $\mathrm{FE}=(\% \mathrm{CPX} 4)+(\%$ lipids X 9) + (\% COH X4).

\begin{tabular}{|c|c|c|}
\hline Parameter analysed & Quantity & Reference \\
\hline Moisture & $83.87 \%$ (full body) & [25] \\
\hline \multirow[t]{5}{*}{ Carbohydrate } & $64.33+3.23 \mathrm{~g} / 100 \mathrm{~g}$ dry weight & {$[27]$} \\
\hline & $29.48 \%$ (outer part) & {$[25]$} \\
\hline & $35.41 \%$ (inner part) & \\
\hline & $54.4 \%$ dry weight (mature) & {$[28]$} \\
\hline & $44.9 \%$ dry weight (young) & \\
\hline Soluble Carbohydrate & $31.98+3.66 \mathrm{~g} / 100 \mathrm{~g}$ dry weight & [25] \\
\hline \multirow[t]{3}{*}{ Protein } & $16.47+1.35 \mathrm{~g} / 100 \mathrm{~g}$ dry weight & {$[27]$} \\
\hline & $11.71 \%$ (outer part) & [25] \\
\hline & $4.66 \%$ (inner part) & \\
\hline Free amino acid & $6.48+0.90 \mathrm{~g} / 100 \mathrm{~g}$ dry weight & [27] \\
\hline \multirow[t]{5}{*}{ Fat } & $3.20+0.85 \mathrm{~g} / 100 \mathrm{~g}$ dry weight & [27] \\
\hline & $4.4 \pm 0.18 \%$ dry weight (mature) & {$[28]$} \\
\hline & $2.7 \pm 0.05 \%$ dry weight (young) & \\
\hline & $1.04 \%$ (outer part) & [25] \\
\hline & $0.24 \%$ (inner part) & \\
\hline \multirow[t]{3}{*}{ Ash } & $2.5 \%$ (full body) & {$[25]$} \\
\hline & $14.2 \pm 0.45 \%$ dry weight (mature) & {$[28]$} \\
\hline & $27.6 \pm 0.29 \%$ dry weight (young) & \\
\hline \multirow[t]{5}{*}{ Fibre } & $10.80+1.02 \mathrm{~g} / 100 \mathrm{~g}$ dry weight & {$[27]$} \\
\hline & $12.3 \pm 0.28 \%$ dry weight (mature) & {$[28]$} \\
\hline & $10.8 \pm 0.16 \%$ dry weight (young) & \\
\hline & 0.02 (outer part) & [25] \\
\hline & 0.13 (inner part) & \\
\hline Energy & $336.74 \mathrm{~g}$ calories & [25] \\
\hline
\end{tabular}

nutrition point of view. Numerous species of wild growing mushrooms are extensively preferred to consume as a delicacy over cultivated fungi in many countries of Asia ${ }^{21}$ and central and eastern Europe. ${ }^{22}$ But credible estimation of the nutritive value of the wild growing mushrooms has so far been restricted due to scattered knowledge of their composition and confined report on the availability of their constituents. ${ }^{22}$ The role of A. hygrometricus as food, is considered to be of immense value as local people consume this mushroom with a belief that it cures several agerelated disorders. ${ }^{23}$ Nutritional data accumulated here provide a chemical basis for the health benefits of consuming A. hygrometricus.

Evaluating the nutritive value of mushrooms, the most vital factor is their moisture content, which directly affects the nutrient contents of mushrooms. ${ }^{24}$ The moisture content estimated in A. hygrometricus was $83.87 \%$ which falls in the range $(80-90 \%)$ characterized by researchers. ${ }^{25}$ In dry matter constituent of mushroom, carbohydrates are present in the greatest amounts and forms the major part of mushroom nutrients constituting of about $50-65 \%{ }^{26}$ Findings reveal that, on a dry weight basis, the basidiocarp as a whole is found to be rich in carbohydrate. The total carbohydrate content of A. hygrometricus was estimated to contain between 44.9-64.89\% ${ }^{25-27,28}$ Table 1. Apart from total carbohydrate content, the soluble carbohydrate content of the mushroom is also determined to be $31.98 \pm 3.66 \mathrm{~g} / 100 \mathrm{~g}$ of dry tissue..$^{27}$ Edible mushroom usually contain both sugars and sugar alcohol. In fungal taxa sugar composition generally varies within species. ${ }^{26}$ Studies revealed that A. hygrometricus include many sugars such as D-Glucose, D-Fructose, Trehalose, D-Mannose, D-Ribose, D-Arabinose, D-Xylose and D-Fucose at a concentration of $0.88,0.85,0.50,0.26,0.12,0.21,0.03$ and $0.10 \mathrm{mg} / \mathrm{g}$ dry wt. respectively and also include sugar alcohols like Mannitol, Glycerol, Myo-Inositol and Meso-Erythritol in it at a concentration of $6.52,0.12,0.14$ and $0.02 \mathrm{mg} / \mathrm{g}$ dry wt. respectively ${ }^{28}$ whereas galactose was initially measured with the help of paper chromatography. ${ }^{29}$

Nutritive value of mushroom is predominantly related to their protein content as protein is a vital constituent of dry matter of mushrooms. ${ }^{30}$ Findings showed that, crude protein content of A. hygrometricus do not show much variation and ranged from $14-16.47 \%{ }^{25-27,28}$ Table 1 . Mushroom protein is familiar to comprise of almost all the essential and few nonessential amino acids. The free amino acid content of this mushroom was $6.48 \pm 0.90 \mathrm{~g} / 100 \mathrm{~g}$ of dry thallus. ${ }^{27}$

The fat content in mushroom found to be too low as compared to protein and carbohydrate. The accumulated data on crude fat content of A. hygrometricus is highly comparable although values vary considerably from $1.28-4.4 \%^{25-27,28}$ indicating low fat content.

Based on the crude protein, fat and carbohydrate, the energy content of a food can be estimated. In dry weight, these mushrooms could provide high energy and wild growing mushrooms seem to have higher nutritive value than the cultivated species. ${ }^{31}$ Energy content of A. hygrometricus has been calculated to be high (336.74 g calories) declaring the mushroom as nutritionally superior. ${ }^{25}$

Fresh mushrooms usually consist of both soluble and insoluble fibre. Insoluble fibre found in fresh mushrooms promotes regularity, good bowel health, slow digestion and adds staying power to foods whereas soluble fibre lower low density lipoprotein cholesterol level and combat cardiovascular disease. ${ }^{27}$ Till date, there are only three reports regarding fibre content of $A$. hygrometricus ranging from 0.15 to $12.3 \%^{25,27,28}$ Table 1 . Thus, A. hygrometricus may be treated as fibre rich high energy-low fat food which help to lose heavy weight, maintain healthy body and prevent different types of common diseases.

Mushroom usually consist of 5-12\% of dry matter of ash ${ }^{22}$ and ash content gives a slight rough idea about the mineral content of fruiting bodies. The ash content of young A. hygrometricus was found to be $27.6 \%{ }^{28}$, quite higher than that of some other edible tropical and temperate basidiomes. ${ }^{32,33}$

The fruiting bodies of mushroom is identified as a best source of vitamins as well as higher level of well assimilated mineral element. Researchers observed that mineral content of wild edible mushrooms were higher than the cultivated ones. ${ }^{32,34}$ In A. hygrometricus, two major vitamins i.e., water soluble vitamins, ascorbic acid and thiamine were found to be present in both inner and outer parts in the quantity of 3.26 (outer) and 0.26 (inner) $\mathrm{mg} / 100 \mathrm{~g}$ and 5.23 (outer) and 3.54 (inner) $\mathrm{mg} / 100 \mathrm{~g}$ respectively ${ }^{25}$ and also possess rich source of various minerals that might play important roles in human life. Detail information of mineral content of the edible ectomycorrhizal fungi with associated references are indicated in Table 2.

\section{PHYTOCHEMICALS}

Mushroom own many therapeutic benefits, as they embrace several biologically active compounds. In present day, the secondary metabolites or bioactive compounds isolated from mushrooms have received huge attention for discovering new drugs or lead compounds. The bioactive components from mushrooms are turning into attractive sources of natural antioxidative, antitumor, antiviral, antimicrobial, and immunomodulatory agents. ${ }^{35}$ In recent times different phytochemicals from A. hygrometricus were documented which includes various high and low molecular weight compounds. Most of these phytochemicals were screened for their medicinal possibilities which would be discussed in later sections of this review. 
Table 2: Content of selected macro and micro minerals present in Astraeus hygrometricus.

\begin{tabular}{|c|c|c|c|}
\hline $\begin{array}{l}\text { Type of } \\
\text { mineral }\end{array}$ & $\begin{array}{l}\text { Mineral } \\
\text { Name }\end{array}$ & Quantity & References \\
\hline \multirow[t]{18}{*}{ Macro } & \multirow[t]{4}{*}{$\mathrm{Ca}$} & $2.4 \mathrm{mg} / \mathrm{g}$ dry weight (mature) & \multirow[t]{2}{*}[28]{} \\
\hline & & $0.8 \mathrm{mg} / \mathrm{g}$ dry weight (young) & \\
\hline & & $29.5 \mathrm{mg} / 100 \mathrm{~g}$ (outer part) & \multirow[t]{2}{*}[25]{} \\
\hline & & $25.8 \mathrm{mg} / 100 \mathrm{~g}$ (inner part) & \\
\hline & \multirow[t]{4}{*}{$\mathrm{P}$} & $2.2 \mathrm{mg} / \mathrm{g}$ dry weight (mature) & \multirow[t]{2}{*}[28]{} \\
\hline & & 5.7 mg/g dry weight (young) & \\
\hline & & 935 mg/100g (outer part) & \multirow[t]{2}{*}[25]{} \\
\hline & & 405 mg/100g (inner part) & \\
\hline & \multirow[t]{4}{*}{$\mathrm{Mg}$} & $1.6 \mathrm{mg} / \mathrm{g}$ dry weight (mature) & \multirow[t]{2}{*}{ [28] } \\
\hline & & $1.2 \mathrm{mg} / \mathrm{g}$ dry weight (young) & \\
\hline & & $242 \mathrm{mg} / 100 \mathrm{~g}$ (outer part) & \multirow[t]{2}{*}[25]{} \\
\hline & & 11 mg/100g (inner part) & \\
\hline & \multirow[t]{2}{*}{$\mathrm{S}$} & $1.7 \mathrm{mg} / \mathrm{g}$ dry weight (mature) & \multirow[t]{2}{*}[28]{} \\
\hline & & 5 mg/g dry weight (young) & \\
\hline & \multirow[t]{4}{*}{$\mathrm{K}$} & $12.8 \mathrm{mg} / \mathrm{g}$ dry weight (mature) & \multirow[t]{2}{*}[28]{} \\
\hline & & 26.1 mg/g dry weight (young) & \\
\hline & & $2132 \mathrm{mg} / 100 \mathrm{~g}$ (outer part) & \multirow[t]{2}{*}[25]{} \\
\hline & & 1241 mg/100g (inner part) & \\
\hline \multirow[t]{16}{*}{ Micro } & \multirow[t]{4}{*}{$\mathrm{Fe}$} & $3254 \mathrm{mg} / \mathrm{kg}$ dry weight (mature) & \multirow[t]{2}{*}[28]{} \\
\hline & & 2059 mg/kg dry weight (young) & \\
\hline & & 2.787 ppm (outer part) & \multirow[t]{2}{*}[25]{} \\
\hline & & 2.35 ppm (inner part) & \\
\hline & \multirow[t]{4}{*}{$\mathrm{Zn}$} & 203 mg/kg dry weight (mature) & \multirow[t]{2}{*}[28]{} \\
\hline & & 105 mg/kg dry weight (young) & \\
\hline & & $0.897 \mathrm{ppm}$ (outer part) & \multirow[t]{2}{*}[25]{} \\
\hline & & 0.448 ppm (inner part) & \\
\hline & \multirow[t]{4}{*}{$\mathrm{Mn}$} & $329 \mathrm{mg} / \mathrm{kg}$ dry weight (mature) & \multirow[t]{2}{*}[28]{} \\
\hline & & 81.7 mg/kg dry weight (young) & \\
\hline & & $0.74 \mathrm{ppm}$ (outer part) & \multirow[t]{2}{*}[25]{} \\
\hline & & $0.17 \mathrm{ppm}$ (inner part) & \\
\hline & \multirow[t]{2}{*}{$\mathrm{Cu}$} & $16.5 \mathrm{mg} / \mathrm{kg}$ dry weight (mature) & \multirow[t]{2}{*}[28]{} \\
\hline & & $25.2 \mathrm{mg} / \mathrm{kg}$ dry weight (young) & \\
\hline & \multirow[t]{2}{*}{ B } & $2.4 \mathrm{mg} / \mathrm{kg}$ dry weight (mature) & \multirow[t]{2}{*}[28]{} \\
\hline & & 2.4 mg/kg dry weight (young) & \\
\hline
\end{tabular}

\section{High molecular weight compounds}

Polysaccharides, polysaccharide-protein complexes and proteins are the high-molecular-weight (HMW) components obtained from mushrooms, recognized for their biological activites. ${ }^{36}$ Investigations carried on A. hygrometricus showed the presence of different bioactive molecules like lectins, polysaccharides and protein complexes. Yagi et al (2000) first reported the presence of lectins from A. hygrometricus. ${ }^{37}$ Later Pramanik and Islam (2000) characterized and introduced the first polysaccharide from the aqueous extract of $A$. hygrometricus containing D-galactose, D-glucose and D-galacturonic acid in the ratio of 1.9:0.9:1 (Figure 2a). ${ }^{29}$ In later years Maiti et al (2008) extracted a water-soluble polysaccharide (Figure 2b) from an alkaline extract of the fruits of $A$. hygrometricus containing D-mannose, D-glucose, and L-fucose in a molar ratio of 1:2:1. ${ }^{38}$ Similarly another research group isolated water soluble fraction from this macrofungus which on fractionation through chromatography

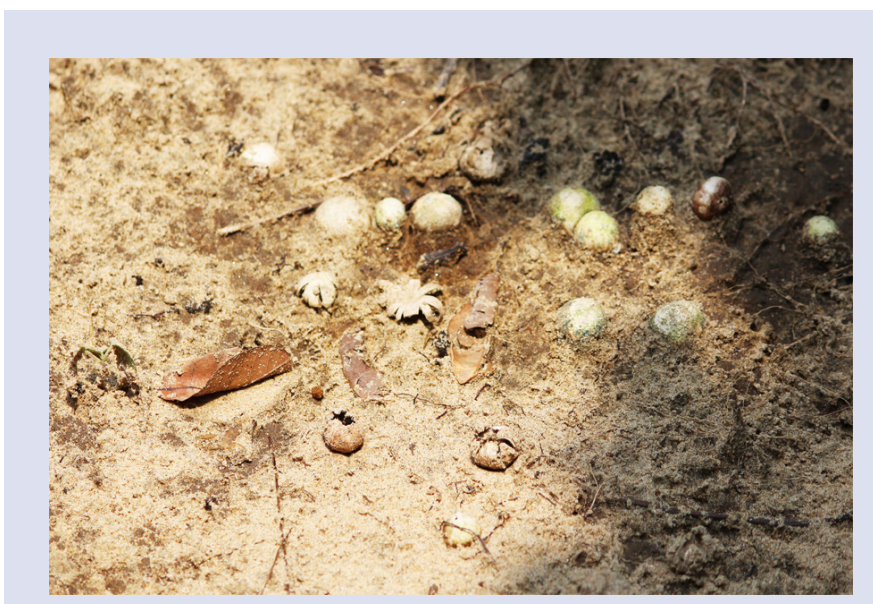

Figure 1: Astraeus hygrometricus in wild condition.

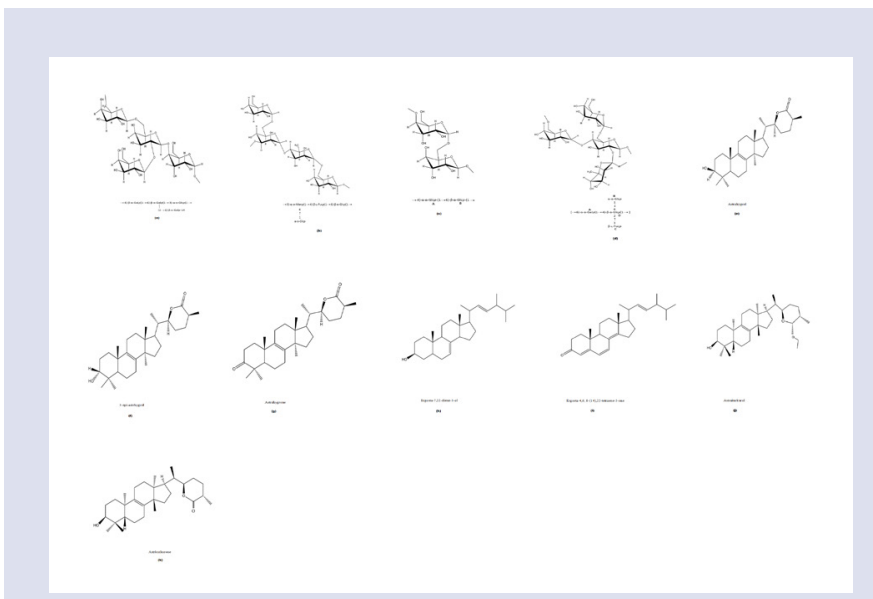

Figure 2: Chemical structures of some phytochemicals isolated from Astraeus hygrometricus.

gave two homogeneous fractions. Fraction I (AQSI) identified as a $\alpha-(1 \rightarrow 4), \beta-(1 \rightarrow 6)$ linked glucan ${ }^{39}$ (Figure $\left.2 c\right)$ and Fraction II (AQS-II) (Figure $2 \mathrm{~d}$ ) found to be a hetero polysaccharide containing $63 \%$ polysaccharide and $35 \%$ protein and the polysaccharide part containing glucose, galactose, and fucose in a 2:1:1 molar ratio. ${ }^{40}$ The molecular weight of these polysaccharide fraction were learnt by a gel-filtration technique and found to be $2.04 \times 10^{5}$ and 22,000 daltons respectively and their structure were established by NMR spectroscopy. ${ }^{39,40}$ Apart from polysaccharide, protein fraction was also obtained from fresh fruiting bodies of $A$. hygrometricus by affinity chromatography and identified as Cibacron blue affinity eluted protein (CBAEP) fraction. ${ }^{41}$ This research group further extended their work by isolating a heteroglucan, designating this group of compound as AE2 which featured a high molecular weight and putative $\beta$-glucan structure consisting of glucose, galactose, mannose and fucose. ${ }^{42}$

\section{Low molecular weight compounds}

Among various low molecular weight bioactive compounds, polyketides and terpenoids are most often reported from Basidiomycetes and Ascomycetes. ${ }^{43}$ Takaishi et al (1987) isolated three new triterpenes called as Astrahygol, 3-epi-Astrahygol and Astrhygrone (Figure 2e, 2f, 2g) and two known steroids from A. hygrometricus and established their structure by chemical and spectroscopic means. Astrahygol $\left(\mathrm{C}_{30} \mathrm{H}_{46} \mathrm{O}_{3}\right)$ 
showed the presence of two secondary and five tertiary methyl groups implying a lanostane skeleton, H NMR spectrum of 3-epi-Astrahygol $\left(\mathrm{C}_{30} \mathrm{H}_{46} \mathrm{O}_{3}\right)$ found very close to that of Astrahygol except that it had a 3 - $\alpha$-hydroxy group instead of 3- $\beta$-hydroxy group and Astrhygrone was obtained from the oxidization of Astrahygol and 3-epi-Astrahygol by Jones reagent. The steroids were confirmed as Ergosta-7,22-diene-3-ol (Figure2h)andErgosta-4,6,8-(14),22-tetraene-3-one(Figure2i) by spectral comparison with literature data. ${ }^{44}$ Later Lai et al (2012) extracted two new sesquiterpenoids, Astrakurkurol $\left(\mathrm{C}_{32} \mathrm{H}_{54} \mathrm{O}_{3}\right)$ and Astrakurkurone $\left(\mathrm{C}_{30} \mathrm{H}_{48} \mathrm{O}_{3}\right)$ from the powdered basidiocarp of $A$. hygrometricus. The fractions were isolated by silica gel column chromatography followed by structural elucidation of the compounds by using various spectroscopic techniques. Astrakurkurol (Figure 2j) was isolated as colorless needles whose molecular mass was 486.7 whereas Astrakurkurone (Figure 2k) was isolated as white amorphous powder with a melting point of $195^{\circ} \mathrm{C} .4^{45}$

\section{MEDICINAL PROPERTIES}

In traditional ancient therapies, medicinal mushrooms have a significant history of its uses. ${ }^{46}$ In different countries, modern clinical practices are continuing to be rely on mushroom-derived preparations. ${ }^{47}$ Astraeus hygrometricus is usually appreciated as herbal medicine in India and China. ${ }^{48}$ Powder form of this mushroom found useful for healing burns, wounds and used as haemastatic agent in Chinese folk medicine. ${ }^{45}$ Apart from nutritional data, scientific evidences acquired from the combination of in vitro and in vivo study of A. hygrometricus has provided a basis for its health-promoting effects. In this section, selected biological activities of $A$. hygrometricus has been discussed in relation to its profess medicinal benefits.

\section{Antioxidative capacity}

Organisms with inherent antioxidant defence systems, are usually not capable enough to completely defend oxidation stress-induced damage. ${ }^{49}$ Thereby recently dietary supplements containing synthetic antioxidants such as butylhydroxytoluene (BHT), propyl gallate, tert-butylhydroxyquinone (TBHQ), butylated hydroxyanisole (BHA) and ethoxyquin (EQ), are highly in demand..$^{50,51}$ However, few synthetic antioxidants under definite conditions may cause unfavourable toxic effects. ${ }^{52,53}$ Recent research works have labelled mushroom as a potential source of dietary antioxidants. ${ }^{49-54,55}$

Astraeus hygrometricus has been immensely studied for its free radical scavenging activity and the resultant $\mathrm{IC}_{50}$ values recommend it as a potential defender against radical induced oxidative stress. Biswas et al (2010) demonstrated strong in vitro antioxidative activity of the ethanolic extract of basidiocarp and was effective for hydroxyl radical scavenging activity, superoxide scavenging activity, DPPH radical scavenging activity, $\beta$-Carotene bleaching inhibition assays and lipid peroxidation inhibition assay. The $\mathrm{IC}_{50}$ value of these experiments were in the range of $81.2-377.27 \mu \mathrm{g} / \mathrm{ml} .^{23}$ Phytochemically the ethanolic extract was rich in phenolic and flavonoid compound which magnifies the antioxidant capacity of the mushroom. ${ }^{56}$ Biswas et al (2010) extended their observation that this mushroom have strong nitric oxide synthase (NOS) activation properties. ${ }^{23}$ It has been strongly documented by the modern day scientific literature that both free radical scavenging and NOS activation are the key players for most killer diseases. ${ }^{57}$

Phenolic rich methanolic extract of this mushroom have rich total antioxidant activity $\left(\mathrm{IC}_{50}\right.$ value of $\left.9.3 \pm 0.3 \mu \mathrm{g} / \mathrm{ml}\right) .{ }^{58}$ The phenolic fraction of plants is usually interlinked to their antioxidant and antimicrobial activity. Singh (2010) quantified several phenolic compounds and found this mushroom to be rich in Protocatechuic acid, Ferulic acid, Salicylic acid, Anthralinic acid and Syringic acid. Total phenolic content was also determined spectrometrically as $1.4 \%$ in inner and outer part of the mushroom repectively. ${ }^{25}$ As A. hygrometricus possessed with phenolic compounds it seems to be a potential source of useful biological drugs.

In another study, a comparative method of antioxidant capacity was performed with raw and cooked fruit bodies of A. hygrometricus which indicated that antioxidant activity significantly decreased on boiling. ${ }^{59}$ Similar observations were found in South-west India where A. hygrometricus is a traditional delicacy. They also investigated that total antioxidant activity decreased upto one-third in cooked mushroom. ${ }^{60}$ After knowing the fact that cooking process reduced the antioxidant activity, it is recommended to consume boiled mushroom tissue as well as their broth to regain some antioxidant activity and retain its nutritive value.

\section{Antimicrobial and Antiparisitic activity}

Antimicrobial agents are widely and often indiscreetly used for therapeutic purposes worldwide. ${ }^{61}$ Emergent resistance of microorganisms against antibiotics due to non-selective use of commercial antimicrobial drugs has generated a serious clinical problem in the treatment of infectious diseases. ${ }^{62,63}$ Numerous compounds extracted from mushrooms were reported to own desirable antifungal and anti-bacterial activity. ${ }^{64,65}$

Antimicrobial activity of this macrofungus was tested with different extracts against Bacillus cereus, Bacillus subtilis, Candida albicans, Escherichia coli, Proteus vulgaris, Pseudomonas aeruginosa and Staphylococcus aureus. Results indicated that $A$. hygrometricus have a narrow range of antimicrobial activity and among the tested strain, Bacillus cereus, Escherichia coli and Staphylococcus aureus were the most susceptible bacteria. All the extracts showed different levels of sensitivity towards the pathogenic microbes in in vitro condition and because of low antimicrobial activities of all the extracts, the minimal inhibitory concentration was not analysed. ${ }^{56}$ Similar antimicrobial activity was tested with methanolic extract against three gram negative bacteria namely Proteus vulgaris, Escherichia coli, Pseudomonas aeruginosa and a yeast Candida albicans which exhibited strong inhibitory activity. ${ }^{66}$ Further extension of this observation lead to the isolation of two pure lanostane type triterpenoid which showed remarkable anticandidal activity against the pathogenic strain, Candida albicans, which is completely resistant to antifungal drugs such as nystatin, fluconazole, and amphotericin-B. ${ }^{45}$

Leishmania donovani, a harmful protozoan parasite is the causative agent of visceral Leishmaniasis that has caused high morbidity and mortality throughout the world. Antileishmanial drugs that are available in market, have raised questions due to their ineffectiveness, severe toxicity and side effects. ${ }^{67}$ Mushroom and its metabolites are developing as costeffective alternative therapeutic strategy against Leishmania donovani. ${ }^{68,69}$ Mallick et al (2014) first worked with different extracts of A. hygrometricus to understand its anti-leishmanial activites where they had demonstrated that terpenoid fraction (AHFa) significantly seize the proliferation of L. donovani promastigotes in vitro by inducing apoptosis and water soluble polysaccharide fraction ( $\mathrm{AHFb}$ ) inhibited intracellular amastigotes in vitro by considerably releasing the essential anti-leishmanial molecule, $\mathrm{NO}$ and pro inflammatory cytokine IL-12. ${ }^{68}$ Previously Lai et al (2012) made a preliminary study using an active compound Astrakurkurone which have exhibited a significant promastigocidal activity against Leishmania donovani promastigotes. ${ }^{45}$ The mechanism behind the promastigocidal activity of astrakurkurone was unveiled by Mallick et al (2015) where the proliferation of $L$. donovani promastigotes were inhibited by astrakurkurone by selective ROS production leading to mitochondrial dysfunction as well as depleting reduced glutathione. Astrakurkurone seen to be quite effective against clinically important intracellular amastigotes, with significant low $\mathrm{IC}_{50}$ of $2.5 \mu \mathrm{g} / \mathrm{ml} .{ }^{69}$ Further extension of their study demonstrated that astrakurkurone boost the immune efficiency of host cells by generating protective cytokines, interleukin 17 and $\gamma$-interferon leading to parasite clearance both 
in vitro and in vivo. Above that, astrakurkurone was found safe for immunosuppressive patients with visceral leishmaniasis. ${ }^{70}$ Thus, detailed study against promastigotes opened an evident possibility for astrakurkurone as a potential source of non-toxic anti-leishmanial molecule.

\section{Anti-diabetic activity}

Diabetes mellitus, or simply, diabetes is a life-threatening chronic metabolic disease affecting more than 180 million people worldwide, is caused by lack of insulin or insulin dysfunction, characterized by higher level of glucose in blood. ${ }^{71,72}$ Mushroom extracts were widely used as an ideal therapeutic food for diabetic patient's due to their high fibre and low-fat content. ${ }^{73}$

Study showed a remarkable hypoglycemic action of ethanolic extract produced from A. hygrometricus on alloxan-induced diabetic mice. Orally administrated ethanolic extract at a dose of $500 \mathrm{mg} / \mathrm{kg}$ of body weight decreased the blood glucose levels in both acute and subacute study. The dose seemed to improve the tolerance for glucose signifying augmented peripheral glucose utilization in the animal model at the time of the oral glucose tolerance test. ${ }^{74}$ Moreover, it was found that mushrooms with higher amount of mannitol are considered as a useful food for diabetic patient and A. hygrometricus found to contain higher amount of mannitol. ${ }^{28}$ Hence $A$. hygrometricus when taken in adequate quantities can serve as medicinal food for diabetic patient.

\section{Hepatoprotective activity}

Liver damage being a global disorder usually caused by oxidative stress, ${ }^{75}$ alcohol, carbon tetrachloride, galactosamine, paracetamol; chemotherapeutic agents and antitubercular drugs are causing hepatotoxicity and severe liver damage. ${ }^{76,77}$ Throughout the world, studies have revealed that natural antioxidants may function in curing certain hepatic damages. ${ }^{78}$ Hepatoprotective properties have also been reported for mushroom extracts and mushroom-derived molecules. ${ }^{75}$

Current studies of Biswas et al (2011) revealed the hepatoprotective action of the ethanolic extract of $A$. hygrometricus against $\mathrm{CCl}_{4}$ induced chronic hepatotoxicity in animal model. Results indicated that antioxidants present in the extract might terminate the chain reaction cascade of $\mathrm{CCl}_{4}$ intoxication by scavenging the intermediates free radicals. Treatment with extract decreased the serum markers like glutamate pyruvate transaminase, glutamate oxaloacetate transaminase, bilirubin and alkaline phosphatase towards normal as well as augmented the antioxidant defence enzymes of liver. Histopathological studies also supported the data. $^{79}$

\section{Cardioprotective activity}

Cardiac hypertrophy and ensuing heart failure is one of the most recognized sources of death in worldwide. ${ }^{80}$ Nitric oxide, an inhibitor of platelet aggregation has been reported to develop favourable effects under various cardiovascular conditions through the increase of both cyclic AMP and GMP levels that inhibits platelet aggregation both in vitro and in vivo. ${ }^{81}$ Mushrooms are an upcoming component in the development of dietary supplements and functional foods that are now utilised to prevent cardiovascular problems. The fatty acid profiles of various mushroom seem to contribute to the reduction of cholesterol levels in the serum. ${ }^{82,83}$ In view of Biswas et al (2011) ethanolic extract of A. hygrometricus can inhibit platelet aggregation, prostaglandin synthesis and stimulate NO synthesis in human blood platelets thereby reducing the incidence of myocardial infraction, cardiac hypertrophy and vascular death among patients with cardiovascular ailment. ${ }^{81}$ This suggest that ethanolic extract of A. hygrometricus might have a role in preventing the development and progression of coronary artery disease as well as might act as fresh remedial approach against cardiac hypertrophy.

\section{Immunomodulatory activity}

In recent time, many bioactive compounds were isolated from mushrooms and among which immunomodulators have gained much attraction based on their rising growth in the immunotherapy sector. Mushroom being natural source of immunomodulating agent are safer substitutes to chemical drugs in medicine. ${ }^{84}$

Water-soluble Fraction I, isolated from the aqueous extract of the A. hygrometricus fruit bodies exhibited strong splenocyte activation at a dose of $10 \mathrm{ng} / \mathrm{mL}$ and stimulates T cells, B cells, macrophages, and thereby promote the immune responses. ${ }^{39}$ Another polysaccharide designated as AE2 studied for macrophage-stimulating activity displayed enhanced production of nitric oxide and cytokines. AE2-treated macrophages showed amplified phagocytic potential ${ }^{42}$ and activated immune cells as well as enhanced cytokine production from splenocytes in in vitro culture. ${ }^{17}$

Protein fraction, Cibacron blue affinity eluted protein (CBAEP) isolated from this mushroom had a stimulatory effect on splenocytes, thymocytes and bone marrow cells within the animal model. Further it intensified the mouse natural killer cell cytotoxicity and activated macrophages to produce NO. ${ }^{41}$ These findings will be useful in considering $A$. hygrometricus as a possible source of an immunomodulator. Mushroom-derived polysaccharides are usually being explored for therapeutic properties for a prolong time, but their way of action of immunomodulatory properties is not well established. Macrophages and monocytes recognize glucans or heteroglucans through the interaction with cell surface receptors such as Scavenger receptors, Dectin1, Toll-like receptors ${ }^{85-87}$ and activate Akt, MAPKs (mitogen-activated protein kinases) pathway. Mallick et al (2011) documented the involvement of p38 MAPK pathways, PKC, MEK (MAPK/ERK kinase), ERK1/2 and JNK in the activation of RAW cells using AE2, whereas it failed to induce phosphorylation of JAK2/ STAT1 pathway. ${ }^{88}$

\section{Anti-inflammatory activity}

Inflammation is regarded as the complex biological response to expel injury or harmful stimuli such as pathogens, damaged cells or irritation ${ }^{89}$ and found to be involved in the development of several chronic diseases such as arthritis, arteriosclerosis, obesity, diabetes, neurodegenerative diseases and cancer. ${ }^{90}$ The nonsteroidal anti-inflammatory drugs that are commonly administrated to reduce inflammation in the body have shown to possess significant side effects. ${ }^{91,92}$ Present studies demonstrated that presence of bioactive compounds in whole mushrooms and their extracts may present efficacious anti-inflammatory activity. ${ }^{90}$ Ethanolic extract of $A$. hygrometricus exhibited noteworthy anti-inflammatory effect as demonstrated by Biswas et al which is very much comparable to that of nonsteroidal anti-inflammatory drugs. Phytochemically the extract is rich in phenol and flavonoids which enhance the capacity to prevent both acute and chronic inflammation in laboratory animal model where acute oedema was induced by carrageenan and dextran and chronic inflammation in paw was induced by formalin..$^{93}$

\section{Anticancer activity}

Cancer is the second largest cause of death in worldwide in people of various ages and background. The common anti-cancer drugs accessible in market produce various side-effects and create hurdle in clinical management. ${ }^{94}$ Selected mushrooms of higher Basidiomycetes known to be effective against cancer for many years ${ }^{95}$ and its antitumor activity has been first demonstrated by Lucas et al (1957). ${ }^{96}$ In recent years, the notable effect of mushrooms and their metabolites drawn the attention of scientists for their antineoplastic activity. ${ }^{97}$

Astraeus hygrometricus demonstrated strong chemopreventive activity as explained by Biswas et al (2012). Ethanolic extract containing chemopreventive agents strongly inhibited cancer by initiating cell cycle de-regulation and apoptosis on Ehrlich's ascites carcinoma cells grown in 
animal model. The apoptogenic action of the extract might be expressed as a result of the occurrence of antioxidant phenolic and flavonoid compounds. ${ }^{98}$ Furthermore, the same ethanolic extract of $A$. hygrometricus was found as a powerful activator of NOS enzyme ${ }^{23}$ and it had been formerly reported that nitric oxide synthase (NOS) activation had an inhibitory effect on various types of cancers including Ehrlich's ascites carcinoma. ${ }^{99,100}$ This might be an added value on the inhibition of Ehrlich's ascites carcinoma.

Heteroglucan, AE2 obtained from A. hygrometricus, exhibited significant antitumor activity. It was noted that administration of AE2 to tumourbearing mice significantly reduced the tumour growth, prolonged their survival rate and instigated the reversal of tumour-mediated immunosuppression. ${ }^{101}$ However, the underlying mechanism of immunoactivation wants further investigation. In another study the bioactive protein fraction, CBAEP from A. hygrometricus showed antiproliferative properties in a mouse model through the induction of apoptosis in tumor cell lines of Mouse melanoma (B16-F0), colon cancer (HT-29), HeLa, Dalton's lymphoma (DL) and sarcoma- $180 .^{41}$

\section{CONCLUSION}

Although limited number of investigations were carried on medicinal and nutritional aspects of $A$. hygrometricus. But from this literature review, it's evident that $A$. hygrometricus have tremendous potentiality in preventing many human ailments. Many endeavours are needed to explore this mushroom, as various bioactive compounds have been identified from this macrofungus but only a few of them are known with their biological activities, so further in-depth study should be carried on the mechanism of action as data in this regard is not satisfactory. Additional work should be directed with this indigenous mushroom to explore the possibility of its utilization or domestication for further processing and their utilization in nutraceutical preparations.

\section{ACKNOWLEDGEMENT}

The present work does not include any funder to acknowledge.

\section{REFERENCES}

1. Rathee S, Rathee D, Rathee D, Kumar V, Rathee P. Mushrooms as therapeutic agents. Rev bras farmacogn. 2012;22(2):459-74.

2. Oboh G, Shodehinde SA. Distribution of nutrients, polyphenols and antioxidant activities in the pilei and stipes of some commonly consumed edible mushrooms in Nigeria. Bull Chem Soc Ethiop. 2009;23(3):391-8.

3. AoT, Deb CR, Khruomo N. Wild edible mushrooms of Nagaland, India: A potentia food resource. Journal of Experimental Biology and Agricultural Sciences. 2016;4(1)59-65.

4. Wasser SP, Weis AL. Therapeutic effects of substances occurring in higher Basidiomycetes mushrooms: A modern perspective. Crit Rev Immunol. 1999;19(1):65-96.

5. Johnsy G, Sargunam SD, Dinesh MG, Kaviyarasan V. Nutritive Value of Edible Wild Mushrooms Collected from the Western Ghats of Kanyakumari District. Botany Research International. 2011;4(4):69-74.

6. Manzi P, Gambeli L, Marconi S. Nutrients in edible muchrooms: An inter-species comparative study. Food Chem. 1999;65(4):477-82.

7. Khan MA, Tania M. Nutritional and Medicinal Importance of Pleurotus Mushrooms: An Overview. Food Rev Int. 2012;28(3):313-29.

8. Valverde ME, Hernandez-PerezT, Paredes-Lopez O. Edible mushrooms: improving human health and promoting quality life. Int J Microbiol. 2015; p.14.

9. Lloyd CG. The Geastrae. In: Stevenson JA, editor. The Mycological Writings. Cincinnati. 1902;p. 1-44.

10. Pavithra M, Greeshma AA, Karun NC, Sridhar KR. Observations on the Astraeus spp. of Southwestern India. Mycosphere. 2015;6(4):421-32.

11. Morgan AP. North American Fungi: The Gastromycetes. Journal Cincinnati Society Natural History. 1889:12:8-22.

12. Ahmad S. Studies in gasteromycetes. Sydowia. 1950;4:124-9.

13. Biswas G, Sagartirtha Sarkar S, Acharya K. Evaluation of pharmacognostic profile of Astraeus hygrometricus (Pers) Morg. J. Botan. Soc. Bengal.
2009;63(1):25-30

14. Roy S, Samajpati NI. Fungus flora of the Bankura district and its adjoining areas. Ind. J. Mycol. Res. 1976; 14(1-2):19-29.

15. Purkayastha RP, Chandra A. Manual of Indian Edible Mushrooms. Today and Tomorrow's Printers and Publishers, New Delhi. 1985.

16. Shajahan MD, Samaipati N. Ectomycorrhizal fungi of Shorea robusta G.f. from West Bengal. J. Mycopathol Res. 1995;33(2):105-17.

17. Mallick SK, Maiti S, Bhutia SK, MaitiTK. Immunostimulatory properties of a polysaccharide isolated from Astraeus hygrometricus. J Med Food. 2010;13(3):665-72.

18. Phosri C, Watling R, Martin MP, Whalley AJS. The genus Astraeus in Thailand. Mycotaxon. 2004;89(2):453-63.

19. Phosri C, Martin MP, Watling R. Astraeus: hidden dimensions. IMA Fungus. 2013;4(2):347-56

20. Nouhra ER, Dominguez L. The first record of Astraeus hygrometricus from Argentina. Mycologist. 1998;12(3):112-3

21. Kumar K. Role of edible mushroom as functional foods- A review. South Asian Journal of Food Technology and Environment. 2015;1(3-4):211-8.

22. Pavel Kalac. Chemical composition and nutritional value of European Species of Wild growing mushrooms: A review. Food Chem. 2009;113(1):9-16.

23. Biswas G, Chatterjee S, Sarkar S, Acharya K. Evaluation of Antioxidant and Nitric Oxide Synthase Activation Properties of Astraeus hygrometricus (Pers) Morg. Int. J. of Biomed. Pharm. Sci. 2010;4(1):21-6.

24. Diez VA, Alvarez A. Compositional and Nutritional studies on two wild edible mushrooms from North West spain. Food Chem. 2001;75(4):417-42.

25. Singh N. Edible Potential of Wild Mushroom Astraeus hygromatricus (Pers) Morg. Nature Environment and Pollution Technology. 2010;9(3):597-600.

26. Wani BA, Bodha $\mathrm{RH}$, Wani $\mathrm{AH}$. Nutritional and medicinal importance of mushrooms. J Med Plant Res. 2010;4(24):2598-604.

27. Biswas G, Sarkar S, Acharya K. Proximate analysis of Astraeus hygrometricus (Pers) Morg. J. Mycopathol. Res. 2010;48(1):155-8.

28. Sanmee R, Dellb B, Lumyongc P, Izumorid K, Lumyong S. Nutritive value of popular wild edible mushrooms from northern Thailand. Food Chem. 2003;82(4):527-32.

29. Pramanik A, Islam SS. Structural studies of a polysaccharide isolated from an edible mushroom, Astraeus hygrometricus. Indian Journal of Chemistry. 2000;39:525-9

30. Wang XM, Zhang J, Wu LH, Zhao YL, LiT, Li JQ, et al. A mini-review of chemical composition and nutritional value of edible wild-grown mushroom from China. Food Chem. 2014;151:279-85.

31. Woldegiorgis AZ, Abate D, Haki GD, Ziegler GR. Proximate and Amino Acid Composition of Wild and Cultivated Edible Mushrooms Collected from Ethiopia. Journal of Food and Nutrition Sciences. 2015:3(2): 48-55

32. Aletor VA. Compositional studies on edible tropical species of mushrooms. Food Chem. 1995;54(3):265-8

33. Leon-Guzma MF, Silva I, Lopez MG. Proximate chemical composition, free amino acid contents, and free fatty acid contents of some wild edible mushrooms form Queretaro, Mexico. J Agric Food Chem. 1997:45(11):4329-32.

34. Rudawska M, LeskiT. Macro and micro elemental contents in fruiting bodies of wild mushrooms from the Netecka forest in west-central Poland. Food Chem. 2005;92(3):499-502

35. Xu X, Yan H, Chen J, Zhang X. Bioactive proteins from mushrooms. Biotechnol Adv. 2011;29(6):667-74.

36. Zhang M, Cui SW, Cheung PCK, Wang Q. Antitumor polysaccharides from mushrooms: A review on their isolation process, structural characteristics and antitumor activity. Trends Food SciTechnol. 2007;18(1):4-19.

37. Yagi F, Sakai T, Shiraishi N, Yotsumot M, Mukoyoshi R. Hemagglutinins (lectins) in fruit bodies of Japanese higher fungi. Mycoscience. 2000;41(4):323-30.

38. Maiti D, Chandra K, Mondal S, Ojha AK, Das D, Roy SK, et al. Isolation and characterization of a heteroglycan from the fruits of Astraeus hygrometricus. Carbohydr Res. 2008;343(4):817-24.

39. Chakraborty I, Mondal S, Pramanik, M, Rout D, Islam SS. Structural investigation of a water-soluble glucan from an edible mushroom, Astraeus hygrometricus. Carbohydr Res. 2004;339(13):2249-54

40. Chakraborty I, Mondal S, Rout D, Chandra K, Islam SS. Structural investigation of a heteroglycan isolated from the fruit bodies of an ectomycorrhizal fungus Astraeus hygrometricus. Carbohydr Res. 2007;342(7):982-7.

41. Maiti S, Bhutia SK, Mallick SK, Kumar A, Khadgi N, Maiti TK. Antiproliferative and immunostimulatory protein fraction from edible mushrooms. Environ Toxicol Pharmacol. 2008;26(2):187-91.

42. Mallick SK, Bhutia SK, Maiti TK. Macrophage stimulation by polysaccharides isolated from barometer earthstar mushroom, Astraeus hygrometricus (Pers) Morgan (Gasteromycetideae). Int J Med Mushrooms. 2009;11(3):237-48.

43. Silva DDD, Rapior S, Sudarman E, Stadler M, Xu J, Alias SA, et al. Bioactive metabolites from macrofungi: ethnopharmacology, biological activities and chemistry. Fungal Divers. 2013;62(1):1-40.

44. Takaishi Y, Murakami Y, Ohashi T, Nakano K, Murakami K, Tomimatsu T. Three triterpenes from Astraeus hygrometricus. Phytochemistry. 1987;26(8):2341-44. 
45. Lai TK, Biswas G, Chatterjee S, Dutta A, Pal C, Banerji J, et al. Leishmanicidal and anticandidal activity of constituents of Indian edible mushroom Astraeus hygrometricus. Chem Biodivers. 2012;9(8):1517-24.

46. Wasser SP. Current findings, future trends, and unsolved problems in studies of medicinal mushrooms. Appl Microbiol Biotechnol. 2011;89(5):1323-32.

47. Zaidman B, Majed MYJ, Wasser SP. Medicinal mushroom modulators of molecular targets as cancer therapeutics. Appl Microbiol Biotechnol. 2005;67(4):453-68

48. Mortimer PE, Karunarathna SC, Li Q, Gui H, Yang X, Yang X, et al. Prized edible Asian mushrooms: ecology, conservation and sustainability. Fungal Divers. 2012;56(1):31-47

49. Khatua S, Paul S, Acharya K. Mushroom as the Potential Source of New Generation of Antioxidant:A Review. Res J Pharm Technol. 2013;6(5):496-505.

50. Sherwin ER. Food additives. In: Branen AL, Davidson PM, Salminen S, Marcel Dekker, editors. New York; 1990.p.39-93.

51. Venkatesh R, Sood D. Review of the Physiological Implications of Antioxidants in Food Interactive Qualifying; Project Report; Faculty of the Worcester Polytechnic Institute: Worcester, MA, USA. 2011.p.1-72.

52. Ferreira ICFR, Barros L, Abreu RMV. Antioxidants in wild mushrooms. Curr Med Chem. 2009;16(12):1543-60.

53. Kozarski MS, Klaus AS, Niksic MP, Griensven LJLD, Vrvic MM, Jakovljevic DM. Polysaccharides of higher fungi: Biological role, structure and antioxidative activity. Chem Ind. 2014;68(3):305-20.

54. Kozarski M, Klaus A, Jakovljevic D, Todorovic N, Vunduk J, Petrovic P, et al. Review Antioxidants of Edible Mushrooms. Molecules. 2015;20(10):19489-525

55. Aggarwal P, Sharma P, Sharma S, Aggarwal J. Antioxidant mushrooms: A review. International Research Journal of Pharmacy. 2012;3(6):65-70.

56. Biswas G. Studies on the medicinal properties of Astraeus hygrometricus (Pers) Morg. Thesis, Calcutta University, Calcutta, India. 2012.

57. Acharya K, Giri S, Biswas G. Comparative study of antioxidant activity and nitric oxide synthase activation property of different extracts from Rhododendron arboreum flower. Int J Pharmtech Res. 2011;3(2):757-62.

58. Ullah BF, Khan MU, Mumtaz AS, Malik RN. Pharmacological activities of selected wild mushrooms in South Waziristan (FATA), Pakistan. H. S Afr J Bot. 2015;97:107-10

59. Kettawan A, Chanlekha K, Kongkachuichai R, Charoensiri R. Effect of cooking on Antioxidant activities and Polyphenol content of edible mushroom commonly consumed in Thailand. Pakistan Journal of Nutrition. 2011;10(11):1094-103.

60. Pavithra M, Sridhara KR, Greeshma AA, Yokotani KT. Bioactive potential of the wild mushroom Astraeus hygrometricus in South-west India. Mycology. 2016;7(4):191-202

61. Leekha S, Terrell CL, Edson RS. General Principles of Antimicrobial Therapy Mayo Clin Proc. 2011;86(2):156-67.

62. Peres-Bota D, Rodriguez H, Dimopoulos G, DaRos A, Mélot C, Struelens MJ, etal. Are infections due to resistant pathogens associated with a worse outcome in critically ill patients? J Infect. 2003;47(4):307-16.

63. Karaman I, Sahin F, Gulluce M, Ogutcu H, Hsengu IM, Adiguzel A. Antimicrobial activity of aqueous and methanol extracts of Juniperus oxycedrus L. J. Ethnopharmacol. 2003;85(2):231-5.

64. Alves MJ, Ferreira ICFR, Dias J, Teixeira V, Martins A, Pintado M. A Review on Antimicrobial Activity of Mushroom (Basidiomycetes) Extracts and Isolated Compounds. Planta Med. 2012;78(16):1707-18.

65. Alves MJ, Ferreira ICFR, Dias J, Teixeira V, Martins A, Pintado M. A Review on Antifungal Activity of Mushroom (Basidiomycetes) Extracts and Isolated Compounds. Curr Top Med Chem. 2013;13(21):2648-59.

66. Giri S, Biswas G, Pradhan P, Mandal SC, Acharya K. Antimicrobial Activities of Basidiocarps of Wild Edible Mushrooms of West Bengal, India. Int J Pharm Tech Res. 2012;4(4):1554-60.

67. Valadares DG, Duarte MC, Oliveira JS, Chávez-Fumagalli MA, Martins VT, Costa $\mathrm{LE}$, et al. Leishmanicidal activity of the Agaricus blazei Murill in different Leishmania species. Parasitol Int. 2011;60(4):357-63

68. Mallick S, Dutta A, Dey S, Ghosh J, Mukherjee D, Sultana SS, et al. Selective inhibition of Leishmania donovani by active extracts of wild mushrooms used by the tribal population of India: An in vitro exploration for new leads against parasitic protozoans. Exp Parasitol. 2014;138:9-17.

69. Mallick S, Dey S, Mandal S, Dutta A, Mukherjee D, Biswas G, et al. A nove triterpene from Astraeus hygrometricus induces reactive oxygen species leading to death in Leishmania donovani. Future Microbiol. 2015;10(5):763-89.

70. Mallick S, Dutta A, Chaudhuri A, Mukherjee D, Dey S, Halder S, et al. Successful therapy of murine visceral leishmaniasis with astrakurkurone, a triterpene isolated from the mushroom Astraeus hygrometricus, involves the induction of protective cell-mediated immunity and TLR9. Antimicrob Agents Chemother 2016;60(5):2696-708.

71. Kaur A, Dhingra GS, Shri R. Antidiabetic Potential of Mushrooms. Asian J Pharm Res. 2015;5(2):111-25.

72. Smith KJ, Page V, Gariepy G, Beland M, Badawi G, Schmitz N. Self-rated diabetes control in a Canadian population with type 2 diabetes: associations with health behaviours and outcomes. Diabetes Res Clin Pract. 2012;95(1):162-8.

73. Acharya K. Medicinal Properties of mushrooms. Advances in Medicinal Plant
Research. 2007.p.215-36.

74. Biswas G, Acharya K. Hypoglycemic activity of ethanolic extract of Astraeus hygrometricus (pers) morg. in alloxan-induced diabetic mice. Int J Pharm Pharm Sci. 2013;5(1)391-4.

75. Chatterjee A, Acharya K. Include mushroom in daily diet-A strategy for better hepatic health. Food Reviews International. 2016;32(1):68-97.

76. Saleem TSM, Chetty CM, Ramkanth S, Rajan VST, Mahesh KK, Gauthamank K Hepatoprotective herbs-A review. Int J Res Pharm Sci. 2010;1(1):1-5.

77. Chatterjee S, Dey A, Dutta R, Dey S, Acharya K. Hepatoprotective effect of the ethanolic extract of Calocybe indica on mice with $\mathrm{CCl}_{4}$ hepatic intoxication. Int J Pharmtech Res. 2011;3(4):2162-8.

78. Muriel P. Role of Free radicals in liver diseases. Hepatol Int. 2009;3(4):526-36.

79. Biswas G, Sarkar S, Acharya K. Hepatoprotective activity of the ethanolic extract of Astraeus hygrometricus (pers) morg. Dig J Nanomater Biostruct. $2011 ; 6(2): 637-41$.

80. Cheng W, Li B, Kajstura J, Li P, Wolin MS, Sonnenblick EH, et al. Stretch-induced programmed myocyte cell death. J Clin Invest. 1995;96(5):2247-59.

81. Biswas G, Rana S, Sarkar S, Acharya K. Cardioprotective activity of ethanolic extract of Astraeus hygrometricus (pers) morg. Pharmacologyonline. 2011;2:808-17.

82. Barros L, Baptista P, Correia DM, Morais JS, Ferreira ICFR. Effects of Conservation Treatment and Cooking on the chemical composition and Antioxidant Activity of Portuguese wild edible mushrooms. J Agric Food Chem. 2007;55(12):4781-8.

83. Mauger JF, Lichtenstein AH, Ausman LM, Jalbert SM, Jauhiainen M, Ehnholm $C$, et al. Effect of different forms of dietary hydrogenated fats on LDL particle size. Am J Clin Nutr. 2003;78(3):370-5.

84. El-Enshasye HA, Hatti KR. Mushroom immunomodulators: unique molecules with unlimited applications. Trends Biotechnol. 2013;31(12):668-77.

85. Mueller A, Raptis J, Rice PJ, Kalbfleisch JH, Stout RD, Ensley HE, et al. The influence of glucan polymer structure and solution conformation on binding to (1-3)-beta-D-glucan receptors in a human monocyte-like cell line. Glycobiol. 2000;10(4):339-46.

86. Mukhopadhyay S, Gordon S. The role of scavenger receptors in pathogen recognition and innate immunity. Immunobiol. 2004;209(1):39-49.

87. Brown GD, Gordon S. Immune recognition: a new receptor for $\beta$-glucans. Nature. 2001:413(6851):36-7.

88. Mallick SK, Maiti S, Bhutia SK, Maiti TK. Activation of RAW 264.7 cells by Astraeus hygrometricus derived heteroglucan through MAP kinase pathway. Cell Bio Int. 2011;35(6):617-21

89. Elsayed EA, El-Enshasy H, Wadaan MAM, Aziz R. Mushrooms: A Potentia Natural Source of Anti-Inflammatory Compounds for Medical Applications. Mediators Inflamm. 2014;p.15

90. Garcia-Lafuentea A, Moro C, Villares A, Guillamon E, Rostagno MA, Arrigo DM, et al. Mushrooms as a Source of Anti-Inflammatory Agents. Anti-Inflammatory and Anti-Allergy Agents in Medicinal Chemistry. 2010;9(2):125-41.

91. Maroon JC, Bost JW, Maroon A. Natural anti-inflammatory agents for pain relief. Surg Neurol Int. 2010;1:80.

92. Sinha M, Gautam L, Shukla PK, Kaur P, Sharma S, Singh TP. Current perspectives in NSAID-induced gastropathy. Mediators Inflamm. 2013.p.11.

93. Biswas G, Sarkar S, Acharya K. Free Radical Scavenging and Anti-Inflammatory Activities of the Extracts of Astraeus hygrometricus (Pers) Morg. Lat Am J Pharm. 2010;29(4):549-53

94. Patel S, Goyal A. Recent developments in mushrooms as anti-cancer therapeutics: a review. 3 Biotech. 2012;2(1):1-15.

95. Zaidman BZ, Yassin M, Mahajna J, Wasser SP. Medicinal mushroom modulators of molecular targets as cancer therapeutics. Appl Microbiol Biotechnol. 2005:67(4):453-68.

96. Lucas EH, Montesano R, Pepper MS, Hafner M, Sablon E. Tumor inhibitors in Boletus edulis and other holobasidiomycetes. Antibiot Chemother. 1957;7(1):1-4

97. Chatterjee S, Biswas G, Basu SK, Acharya K. Antineoplastic effect of mushrooms: a review. Australian Journal of Crop Science. 2011;5(7):904-11.

98. Biswas G, Chatterjee S, Acharya K. Chemopreventive activity of the ethanolic extract of Astraeus hygrometricus(Pers) Morg. on Ehrlich's ascites carcinoma cells. Dig J Nanomater Biostruct. 2012;7(1):185-91.

99. Sinha AK, Acharya K, Bhattacharya S, Patra SC, Guha M, Ray U, et al. Neutralization of antineoplastin of insulin activated nitric oxide synthase antibody and its effects in cancers. J Cancer Res Clin Oncol. 2002; 128(12):659-68.

100. Chattopadhyay S, Das T, Sa G, Ray PK. Protein A-Activated Macrophages Induce Apoptosis in Ehrlich's Ascites Carcinoma Through a Nitric Oxide-Dependent Pathway. Apoptosis. 2002;7(1):49-57.

101. Mallick SK, Maiti S, Bhutia SK, Maiti TK. Antitumor properties of a heteroglucan isolated from Astraeus hygrometricus on Dalton's lymphoma bearing mouse. Food Chem Toxicol. 2010;48(8):2115-21. 


\section{GRAPHICAL ABSTRACT}

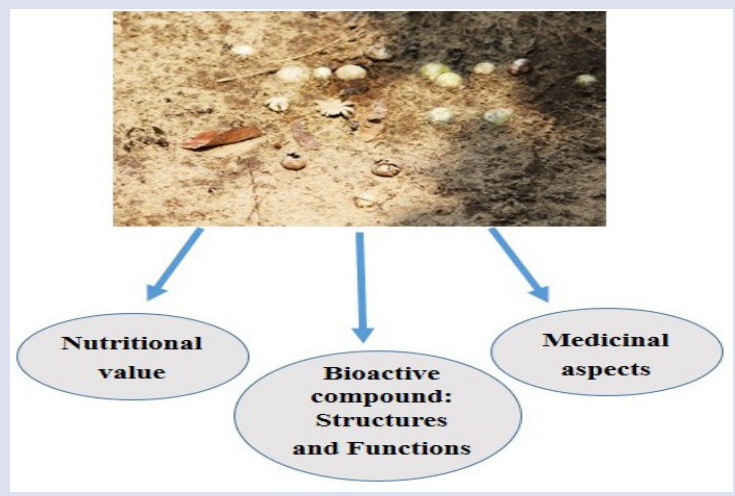

ABOUT AUTHORS

\section{SUMMARY}

- Astraeus hygrometricus, an ectomycorrhizal edible mushroom, commonly consumed by forest dwellers and ethnic people.

- Basidiocarp of this macrofungi contains considerable amount of carbohydrate, protein, fibre, minerals, vitamins, essential amino acids and very minute concentration of fat.

- Astraeus hygrometricus have wide range of medicinal value such as hepatoprotective, cardioprotective, anti-inflammatory, hypoglycaemic, antitumor, anti-leishmanial, anticandidal, antioxidant and immunomodulatory activity which has been highlighted to emphasize its importance to the modern scientific community.

- Astraeus hygrometricus may emerge as a suitable source for application in nutraceutical, functional food and pharmaceutical industries.

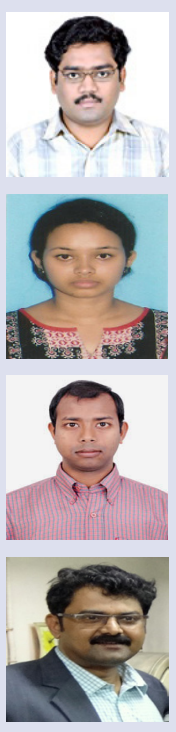

Gunjan Biswas, Ph.D.,Assistant Professor, Department of Botany \& Forestry, Vidyasagar University, Midnapore, West Bengal, India.

Sudeshna Nandi, Research Scholar of Molecular and Applied Mycology and Plant Pathology Laboratory, Department of Botany, University of Calcutta, Kolkata, India.

Debashis Kuila, Research Scholar, Department of Botany \& Forestry, Vidyasagar University, Midnapore, West Bengal, India.

Krishnendu Acharya, M.Sc, M.Tech, Ph.D., Professor, Molecular and Applied Mycology and Plant Pathology Laboratory, Department of Botany, University of Calcutta, Kolkata, India.

Cite this article: Biswas G, Nandi S, Kuila D, Acharya K. A Comprehensive Review on Food and Medicinal Prospects of Astraeus hygrometricus. Pharmacog J. 2017;9(6):799-806. 